\title{
Study on Bio-Efficacy of Zinc Fortified SSP in Soybean
}

\author{
H. H. Dikey ${ }^{1 *}$, R. S. Wankhade ${ }^{2 *}$, S. S. Munje ${ }^{1}$ and Shubhangi Shelke ${ }^{1}$ \\ ${ }^{1}$ Regional Research Centre, Dr. Panjabrao Deshmukh Krishi Vidyapeeth, \\ Amravati-444603, Mahrashtra, India \\ ${ }^{2}$ Agriculture Research Station, Dr. Panjabrao Deshmukh Krishi Vidyapeeth, \\ Achalpur Dist. Amravati- Mahrashtra, India \\ *Corresponding author
}

\begin{tabular}{|l|}
\hline Ke y w o r d s \\
Micronutrient, \\
Carbohydrate, \\
protein, and \\
chlorophyll
\end{tabular}

\section{Introduction}

Soybean has emerged as one of the major oilseed crop and revolutionized rural economy and lifted the socio economic status of soybean farmers. However, the increase in the productivity over the years did follow the same place, and it is not more than half of the world average, hence there is tremendous scope to increase soybean production by enhancing productivity. There are several constraints in the soybean cultivation one of them is nutrient management particularly micronutrients.

Zinc is an important component of various 
enzymes that are responsible for driving many metabolic reactions in all crops. Growth and development would stop if specific enzymes were not present in plant tissue. Carbohydrate, protein, and chlorophyll formation is significantly reduced in zincdeficient plants. Therefore, a constant and continuous supply of zinc is needed for optimum growth and maximum yield.

Zinc $(\mathrm{Zn})$ is an essential micronutrient for plant life. In Minnesota, while some soils are capable of supplying adequate amounts for crop production, addition of zinc fertilizers is needed for others. Zinc is a recommended micronutrient in fertilizer programs for production of soybean. Keeping all this in mind, the studies was conducted to find out the bio-efficacy of zinc fortified SSP on growth and yield of soybean.

\section{Materials and Methods}

A field experiment was carried out at Regional Research Centre, Dr. Panjabrao Deshmukh Krishi Vidyapeeth, Amravati, Mahrashtra during kharif season of the year 2016. A set of six treatments regular SSP, Zincated SSP, regular SSP + recommended dose of zinc sulphate ( $\mathrm{Zn} \mathrm{21 \% )}$ as soil application, zincated SSP +1 foliar spray of zinc sulphate (Zn 21\%), Zincated SSP +2 foliar spray of zinc sulphate ( $\mathrm{Zn} \mathrm{21 \% )}$ and regular SSP +2 foliar spray of zinc sulphate (Zn 21\%) were taken under Randomized Block Design with four replication to evaluate bio-efficacy of zinc fortified SSP in soybean. Two sprays were given 30 and 60 DAS. The soil of experimental field was medium deep black. The crop (Variety JS-335) was raised using nutrient dose @ $30 \mathrm{~kg} \mathrm{~N}, 70 \mathrm{~kg} \mathrm{P}_{2} \mathrm{O}_{5}$ and $30 \mathrm{~kg} \mathrm{~K}_{2} \mathrm{O}$ per hectare at the time of sowing. Seeds were sown at the rate of $75 \mathrm{~kg}$ $\mathrm{ha}^{-1}$ by dibbling method at a spacing of $45 \mathrm{~cm}$ $\mathrm{x} 05 \mathrm{~cm}$.

The data on plant height, no. of branches per plant and no. of pods per plant were collected from randomly selected five plants per plot at the time of harvest. From the total produce of each plot, 100 grains were counted and weighed to express test weight. The crop was harvested when the pods were matured, bundles were sun dried for few days and then threshed manually.

The data on biological and grain yield were collected at the time of harvest. The data were analysed by statistical method as suggested by Panse and Sukhatme (1954).

\section{Results and Discussion}

Treatment T2 (Zincated SSP), T3 (Regular $\mathrm{SSP}+$ recommended dose of zinc sulphate ( $\mathrm{Zn}$ $21 \%$ ) as soil application), T4 (Zincated $\mathrm{SSP}+1$ foliar spray of zinc sulphate (Zn21\%)) and T5 (Zincated SSP +2 foliar spray of zinc sulphate $(\mathrm{Zn} 21 \%))$ was found significantly superior over treatment T1 (Regular SSP) for the characters plant height, Number of pods/plant, 100 Seed weight, Leaf area index.

Treatment T1 (Regular SSP) found at par with treatment T6 (Regular SSP+2 foliar spray of

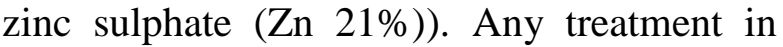
respect of Number of seeds /pod does not show significant effect (Table 1).

Significant increases in plant height was due to vigorous root and shoot growth and establishment of $\mathrm{N}$-fixation by root-nodules activated and requisite level by the applied $\mathrm{P}$ and $\mathrm{Zn}$. These results are in conformity with the findings of Wasmatkaret al (2002), Yadav (2003); Malaviyaet al (2004), Singh and Rai (2004); Tiwari et.al. (2006). The increase of plant height and leaf area due to $\mathrm{Zn}$ application have been reported by Agrawalet al (1996), Khamparia (1996) and Achakzaiet al (2002).

The higher number of pods/plant and other yield-attributing characters may be attributed to the significant role of phosphorus and zinc 
(applied as $\mathrm{ZnSo} 4$ ) in regulating the photosynthesis, root enlargement and better microbial activities (Prasad and Sanoria, 1981).

According to Thakur and Mandloi (1990) and Shinde (1995), the higher number of pods per plant may be due to the fact that applied $\mathrm{P}$ and $\mathrm{Zn}$ (with S) enhanced the metabolic activities promoting chlorophyll formation and photosynthesis at one hand and rootdevelopment coupled with accelerated 65 rhizoidal activity on the other. Moreover, application of phosphorus produced vigorous root development, better nitrogen fixation and overall better development of plant.

This ultimately resulted in increase in yieldattributing characters. Wasmatkar el al. (2002), Chandelet al (2002), Yadav (2003), Singh and Rai (2004) also supported the present results and interpreted that $\mathrm{P}$ and $\mathrm{Zn}$ (with S) enhanced the metabolic activity, promoted chlorophyll and amino acids and protein synthesis which may result in better pod characters. The increases in yieldattributes due to applied-P in soybean have also been supported by the finding of several worker (Khandweet al 2002; Patraet al 2002; Dikshit and Khatik, 2002; Yadav, 2003 Malaviya, 2004).

Treatment T4 i.e Zincated SSP+1 foliar spray of zinc sulphate $(\mathrm{Zn} 21 \%)$ was recorded significantly highest seed yield $(2137 \mathrm{~kg} / \mathrm{ha})$ over treatment $\mathrm{T} 1(1887 \mathrm{~kg} / \mathrm{ha})$ but found at par with T2 (Zincated SSP), T3 (Regular $\mathrm{SSP}+$ recommended dose of zinc sulphate $(\mathrm{Zn}$ $21 \%$ ) as soil application), and T5 (Zincated $\mathrm{SSP}+2$ foliar spray of zinc sulphate (Zn21\%)). Similar trend was also observed in respect of straw yield (Table 2).

Table.1 Growth and yield attributes of soybean as influenced by various treatments

\begin{tabular}{|c|c|c|c|c|c|c|}
\hline Treatments & $\begin{array}{l}\text { plant } \\
\text { height } \\
(\mathrm{cm})\end{array}$ & $\begin{array}{l}\text { No. of } \\
\text { branches } \\
\text { /plant }\end{array}$ & $\begin{array}{l}\text { No of } \\
\text { Pods/ } \\
\text { plant }\end{array}$ & $\begin{array}{l}\text { No of } \\
\text { seeds } \\
\text { / Pod }\end{array}$ & $\begin{array}{c}100 \\
\text { Seed } \\
\text { wt. }(g)\end{array}$ & $\begin{array}{l}\text { Leaf Area } \\
\text { Index at } \\
60 \text { DAS }\end{array}$ \\
\hline T1 Regular SSP & 9.35 & 3.35 & 9.80 & 2.70 & 9.85 & 3.12 \\
\hline T2 Zincated SSP & 44.55 & 3.60 & 21.90 & 2.80 & 10.28 & 3.35 \\
\hline $\begin{array}{l}\text { T3 Regular SSP+recommended } \\
\text { dose of zinc sulphate }(\mathrm{Zn} 21 \%) \text { as } \\
\text { soil application }\end{array}$ & 44.43 & 3.60 & 21.85 & 2.80 & 10.25 & 3.35 \\
\hline $\begin{array}{l}\text { T4 Zincated SSP+1 foliar spray of } \\
\text { zinc sulphate }(\mathrm{Zn} 21 \%)\end{array}$ & 46.20 & 4.05 & 22.30 & 2.80 & 10.35 & 3.36 \\
\hline $\begin{array}{l}\text { T5 Zincated SSP+2 foliar spray of } \\
\text { zinc sulphate (Zn21\%) }\end{array}$ & 44.35 & 3.95 & 22.25 & 2.80 & 10.33 & 3.33 \\
\hline $\begin{array}{l}\text { T6 Regular SSP+2 foliar spray of } \\
\text { zinc sulphate }(\mathrm{Zn} 21 \%)\end{array}$ & 40.75 & 3.50 & 20.05 & 2.75 & 9.98 & 3.21 \\
\hline Test & Sig. & Sig. & Sig. & NS & Sig. & Sig. \\
\hline $\mathrm{SE} \pm(\mathrm{m})$ & 1.43 & 0.15 & 0.66 & 0.10 & 0.12 & 0.06 \\
\hline CD at $5 \%$ & 4.32 & 0.45 & 1.99 & --- & 0.36 & 0.17 \\
\hline
\end{tabular}


Table.2 Effect of treatments on seed yield, straw yield, dry matter accumulation, protein content and oil content of soybean

\begin{tabular}{|c|c|c|c|c|c|c|c|}
\hline \multirow[t]{2}{*}{ Treatments } & \multirow{2}{*}{$\begin{array}{c}\text { Seed } \\
\text { yield } \\
(\mathbf{k g} / \mathrm{ha})\end{array}$} & \multirow{2}{*}{$\begin{array}{l}\text { Straw } \\
\text { yield } \\
\text { (kg/ha) }\end{array}$} & \multicolumn{3}{|c|}{ Dry matter accumulation (g) } & \multirow{2}{*}{$\begin{array}{l}\text { Protein } \\
\text { content } \\
(\%)\end{array}$} & \multirow{2}{*}{$\begin{array}{c}\text { Oil } \\
\text { content } \\
(\%)\end{array}$} \\
\hline & & & 30 DAS & 45 DAS & $\begin{array}{c}60 \\
\text { DAS }\end{array}$ & & \\
\hline T1 Regular SSP & 1887 & 1976 & 1.27 & 7.45 & 10.34 & 37.28 & 19.38 \\
\hline T2 Zincated SSP & 2105 & 2331 & 1.32 & 8.58 & 14.19 & 38.72 & 20.20 \\
\hline $\begin{array}{l}\text { T3 Regular SSP+ recommended } \\
\text { dose of zinc sulphate ( } \mathrm{Zn} 21 \%) \\
\text { as soil application }\end{array}$ & 2103 & 2324 & 1.30 & 8.56 & 13.82 & 38.56 & 20.15 \\
\hline $\begin{array}{l}\text { T4 Zincated SSP+1 foliar spray } \\
\text { of zinc sulphate (Zn 21\%) }\end{array}$ & 2137 & 2518 & 1.31 & 9.11 & 14.31 & 38.96 & 20.35 \\
\hline $\begin{array}{l}\text { T5 Zincated SSP+2 foliar spray } \\
\text { of zinc sulphate ( } \mathrm{Zn} 21 \% \text { ) }\end{array}$ & 2122 & 2460 & 1.30 & 8.46 & 14.19 & 38.87 & 20.23 \\
\hline $\begin{array}{l}\text { T6 Regular SSP+2 foliar spray } \\
\text { of zinc sulphate (Zn 21\%) }\end{array}$ & 1917 & 2100 & 1.28 & 8.03 & 12.95 & 37.51 & 19.53 \\
\hline Test & Sig. & Sig. & NS & Sig. & Sig. & Sig. & Sig. \\
\hline $\mathrm{SE} \pm(\mathrm{m})$ & 65.6 & 95.87 & 0.05 & 0.33 & 0.67 & 0.35 & 0.19 \\
\hline CD at $5 \%$ & 197.7 & 288.87 & -- & 0.99 & 2.03 & 1.07 & 0.57 \\
\hline
\end{tabular}

Table.3 Effect of treatments on monetary returns and B: C Ratio of soybean

\begin{tabular}{|l|l|c|c|c|}
\hline \multicolumn{1}{|c|}{ Treatments } & $\begin{array}{c}\text { Cost of } \\
\text { cultivation }\end{array}$ & $\begin{array}{c}\text { Gross } \\
\text { Monetary } \\
\text { Return }\end{array}$ & $\begin{array}{c}\text { Net } \\
\text { Monetary } \\
\text { Return }\end{array}$ & \multicolumn{1}{|c|}{$\begin{array}{c}\text { B: C } \\
\text { Ratio }\end{array}$} \\
\hline T1 Regular SSP & 30293 & 54857.07 & 24565 & 1.81 \\
\hline T2 Zincated SSP & 31203 & 61379.57 & 30177 & 1.97 \\
\hline $\begin{array}{c}\text { T3 Regular SSP + recommended dose of } \\
\text { zinc sulphate (Zn 21\%) as soil application }\end{array}$ & 30696 & 61327.44 & 30631 & 2.00 \\
\hline $\begin{array}{c}\text { T4 Zincated SSP+ 1 foliar spray of zinc } \\
\text { sulphate (Zn 21\%) }\end{array}$ & 31929 & 62556.14 & 30627 & 1.96 \\
\hline $\begin{array}{c}\text { T5 Zincated SSP+ 2 foliar spray of zinc } \\
\text { sulphate (Zn 21\%) }\end{array}$ & 32294 & 62045.40 & 29751 & 1.92 \\
\hline $\begin{array}{l}\text { T6 Regular SSP+ 2 foliar spray of zinc } \\
\text { sulphate (Zn 21\%) }\end{array}$ & 30696 & 55858.00 & 25162 & 1.82 \\
\hline Test & Sig. & Sig. & NS & - -- \\
\hline SE $\pm(m)$ & 141.91 & 1922.01 & -- & - \\
\hline CD at 5\% & 427.61 & 5791.48 & -- & -- \\
\hline
\end{tabular}


Table.4 Effect of treatments on nutrient uptake by soybean and soil fertility status

\begin{tabular}{|c|c|c|c|c|c|c|c|c|c|c|}
\hline \multirow[t]{2}{*}{ Treatments } & \multicolumn{3}{|c|}{$\begin{array}{l}\text { Total Nutrient } \\
\text { uptake (kg/ha) }\end{array}$} & \multirow[t]{2}{*}{$\mathbf{P H}$} & \multirow[t]{2}{*}{ Ec } & \multicolumn{3}{|c|}{$\begin{array}{l}\text { Available nutrient status in soil } \\
\text { (kg/ha) at harvest }\end{array}$} & \multirow{2}{*}{$\begin{array}{c}\text { Zinc } \\
\text { content } \\
\text { in Seed } \\
(\mathbf{p p m})\end{array}$} & \multirow{2}{*}{$\begin{array}{l}\text { Zinc } \\
\text { content } \\
\text { in Soil } \\
(p p m)\end{array}$} \\
\hline & $\mathbf{N}$ & $\mathbf{P}$ & $\mathbf{K}$ & & & $\begin{array}{l}\text { Available } \\
\text { N }\end{array}$ & $\begin{array}{l}\text { Available } \\
\quad \mathbf{P}\end{array}$ & $\begin{array}{l}\text { Available } \\
\text { K }\end{array}$ & & \\
\hline T1 Regular SSP & 205.7 & 12.7 & 51.5 & 7.41 & 0.36 & 272.20 & 22.61 & 285.75 & 33.73 & 0.651 \\
\hline T2 Zincated SSP & 235.6 & 16.7 & 63.1 & 7.41 & 0.36 & 273.28 & 23.46 & 286.75 & 45.75 & 0.655 \\
\hline $\begin{array}{l}\text { T3 Regular SSP + } \\
\text { recommended dose of zinc } \\
\text { sulphate (Zn } 21 \% \text { ) as soil } \\
\text { application }\end{array}$ & 234.6 & 16.2 & 63.0 & 7.41 & 0.36 & 273.22 & 23.42 & 286.26 & 45.60 & 0.656 \\
\hline $\begin{array}{l}\text { T4 Zincated SSP+ } 1 \text { foliar spray } \\
\text { of zinc sulphate ( } \mathrm{Zn} 21 \%)\end{array}$ & 260.0 & 18.8 & 71.4 & 7.41 & 0.36 & 273.25 & 23.58 & 286.70 & 46.85 & 0.655 \\
\hline $\begin{array}{l}\text { T5 Zincated SSP+ } 2 \text { foliar spray } \\
\text { of zinc sulphate ( } \mathrm{Zn} 21 \%)\end{array}$ & 255.8 & 17.5 & 66.2 & 7.41 & 0.36 & 272.73 & 23.18 & 286.63 & 46.00 & 0.656 \\
\hline $\begin{array}{l}\text { T6 Regular SSP+ } 2 \text { foliar spray } \\
\text { of zinc sulphate (Zn 21\%) }\end{array}$ & 216.9 & 14.2 & 55.0 & 7.41 & 0.36 & 272.30 & 22.82 & 285.80 & 39.88 & 0.653 \\
\hline Test & Sig. & Sig. & Sig. & $7.41 *$ & $0.36 *$ & $268.00 *$ & $21.57 *$ & $285.18 *$ & -- & 0.654 \\
\hline $\mathrm{SE} \pm(\mathrm{m})$ & 7.92 & 0.58 & 2.78 & -- & -- & -- & -- & -- & -- & -- \\
\hline CD at $5 \%$ & 23.85 & 1.74 & 8.78 & -- & -- & -- & -- & -- & -- & -- \\
\hline
\end{tabular}

Note: - * Initial status of soil 
Treatment T2 (Zincated SSP), T3 (Regular $\mathrm{SSP}+$ recommended dose of zinc sulphate ( $\mathrm{Zn}$ $21 \%$ ) as soil application), T4 (Zincated $\mathrm{SSP}+1$ foliar spray of zinc sulphate (Zn21\%)) and T5 (Zincated SSP+2 foliar spray of zinc sulphate (Zn21\%)) was found significantly superior over treatment T1 (Regular SSP) for the characters dry matter accumulation at 45 days, protein content, oil content except treatment T6 (Regular SSP+2 foliar spray of zinc sulphate (Zn21\%)).

Any treatment does not show significant effect in respect of dry matter accumulation at 30 days. For the character dry matter accumulation at 60 days all the treatment i.e. T2, T3, T4, T5 and T6 found significantly superior over treatment $\mathrm{T} 1$ (Table2).

The findings of Jha and Chandal (1987) at Pantnagar revealed that application of zinc increased the plant dry matter, grain yield and yield-attributes and quality (protein and oil content) of soybean grain. The increase in grain yield was mainly due to increase in pods/plant and grains/pod by zinc application. The cannelization of photosynthates during reproductive stage might have been influenced by zinc by way of its involvement in electron transfer (Bakar el al., 1982) and activation of various enzymes (Okhi, 1978).

The increased phosphorus levels also contributed to increase seed and straw yield through the increase in yield-attributing characters.

Treatment T2 (Zincated SSP), T3 (Regular $\mathrm{SSP}+$ recommended dose of zinc sulphate ( $\mathrm{Zn}$ $21 \%$ ) as soil application)), T4 (Zincated $\mathrm{SSP}+1$ foliar spray of zinc sulphate (Zn21\%)) and T5 (Zincated SSP+2 foliar spray of zinc sulphate $(\mathrm{Zn} 21 \%))$ recorded significantly higher GMR over T1 (Regular SSP) whereas in case of $\mathrm{B}: \mathrm{C}$ ratio $\mathrm{T} 3$ recorded highest $\mathrm{B}: \mathrm{C}$ ratio followed by treatment $\mathrm{T} 2, \mathrm{~T} 4$ and $\mathrm{T} 5$
(Table3). Vyaset al (1993) and Shinde (1995) also observed that soybean responded economically to the applied phosphorus levels.

Treatment T2 (Zincated SSP), T3 (Regular $\mathrm{SSP}+$ recommended dose of zinc sulphate (Zn $21 \%$ ) as soil application)), T4 (Zincated $\mathrm{SSP}+1$ foliar spray of zinc sulphate $(\mathrm{Zn} 21 \%)$ ) and T5 (Zincated SSP+2 foliar spray of zinc sulphate $(\mathrm{Zn} 21 \%))$ found significantly superior over treatment T1 (Regular SSP) for the character $\mathrm{N}, \mathrm{P}$ and $\mathrm{K}$ uptake except treatment T6 (Regular SSP+ 2 foliar spray of zinc sulphate ( $\mathrm{Zn} \mathrm{21 \% )}$ ). For the character zinc content in seed all the treatment i.e. T2, T3, T4, T5 and T6 found significantly superior over treatment T1 (Table 4). The results of present investigation suggests that T4 Zincated SSP +1 foliar spray of zinc sulphate ( $\mathrm{Zn} \mathrm{21 \% )}$ leads to highest plant height, no. of branches /plant, no. of pods/plant, 100 seed weight, dry matter accumulation, seed and straw yields of soybean with increased contents of available $\mathrm{N}, \mathrm{P}$ and $\mathrm{K}$ in soil.

\section{References}

Achakzai A K K, Kayani S A, Wahid M A and Shah Jehan. 2002. Effect of fertilizer on growth, moisture content, yield, yield attributes and correlation studies of noninoculated and inoculated soybean growth under Quetta climate. Sarhad Journal of Agriculture 18 (3): 317-22.

Agrawal V K, Dwivedi S K, Shrivastava Sangeeta, Patel R S, Nigam P K and S. Shrivastava. 1996. Influence of phosphorus and zinc application on physiological determination of growth and productivity of soybean (Glycine $\max$ (L.) Merrill). Crop Research 12 (2): 192-5.

Bakar, N.R.; Fernyhough, P. and T.T. Meek,,1982. Light dependent inhibition of photosynthetic electron transport by zinc. Physiology of Plants. 56: 217-222.

Chandal, A.S.; Saxena, S.C.; Kumar, Sushil and 
Prakash, Ram., 2002. Integrated nutrient management for sustainable soybean (Glycine max) production in foot hills of Uttaranchal. Extended Summaries. 76 Vol. 1: 2"d International Agronomy Congress, Nov. 2630, New Delhi, India. pp. 438-439.

Deverajan R and G. Ramanathan, 1995. Direct, residual and cumulative effect of applied $\mathrm{Zn}$ for rice in red soil. Madras Agricultural Journal 82(2): 90-2.

Dubey S B, Patel S B and Y M Sharma. 1999. Zinc management in soybean based cropping system in Vertisols. JNKVV Research Journal 33(1-2): 58-64.

Dikshit, P.R. and S.K. Khatik,.,2002. Influence of organic manures in combination with chemical fertilizers on production, quality and economic feasibility of soybean in typic haplustert of Jabalpur. Legume Research, 25 (1): 53-56.

Jain, P.C. and S.K. Trivedi,., 2005. Response of soybean to phosphorus and biofertilizer. Legume Research, 28 (1): 30-33.

Khamparia N K. 1996. Yield and yield attributing characters of soybean as affected by levels of phosphorus and zinc and their interactions on Vertisols. Crop Research 12(3): 275-82.

Khandwe, Rupendra and R.C. Sharma, 2002. Effect of phosphorus, sulphur and phosphatesolubilizing bacteria on growth and productivity of soybean. J. Oilseeds Res., 19(2): 195-196.

Jha, A.N. and A.S. Chandel, 1987. Response of soybean to zinc application.Indian Journal of Agronomy. 32(4): 354-358.

Malviya, Sanjay; Namdeo, S.L.; Patel, R.N. and D.P. Singh,, 2004. Influence of N and P, FYM and crop residues on growth, nodulation and yield of soybean under rainfed conditions. Annals of Plant and Soil Research, 6 (2): 204205.

Okhi, K.,1978. Zinc Concentration in soybean as related to growth, photosynthesis and carbonic anhydrous activity. Crop Science 18: 79-82.

Panse, V.G. and P.V. Sukhatme,,1978. Statistical Methods for Agricultural Workers. ICAR Publication, New Delhi.

Patra, A.P.; Guchhait, P. and B.R. Behera, 2002. Effect of organic manures and levels of phosphorus on productivity of soybean. Extended Summaries. Vol.1: 2"d International Agronomy Congress. Nov. 26-30, New Delhi, pp. 600-601.

Prasad, J. and C.L. Sanoria,,1981. Response of bengal gram to seed bacterization and phosphorus. Seeds and Farms. 7(4): 31-32.

Shinde, Shailendra,1995. Response of soybean to $\mathrm{P}$ and $\mathrm{S}$ in relation to growth, quality and yield. M.Sc. (Ag.) Thesis, College of Agriculture, Gwalior (M.P.).

Singh, Ranjit and R. K. Rai,,2004. Yieldattributes, yield and quality of soybean as influenced by integrated nutrient management. Indian Journal of Agronomy. 49(4): 271-274.

Thakur, H.S. and K.S. Mandloi,,1990. Effect of different levels and sources of sulphur application on growth, yield and quality of soybean. M.Sc. (Ag.) Thesis, JNKVV, Jabalpur (M.P.).

Tiwari, M.K.; Patel, A.K. and K.N. Namdeo,,2006. Effect of fertility levels and triacontanol on yield quality and nutrient uptake of soybean. Annals of Plant and Soil Research, 8(2): 152-154.

Wasmatkar, R.P.; Ingole, G.L. and P.O. Raut, 2002. Effect of different levels of sulphur and zinc on quality and uptake of nutrient of soybean. Journal of Maharashtra Agricultural Universities. 27(3) : 244-246.

Yadav, L.,2003. Effect varying fertility levels with and without of FYM, sulphur and zinc sulphate on growth and yield of soybean. M.Sc. (Ag.) Thesis, JNKVV, Jabalpur.

\section{How to cite this article:}

Dikey, H. H., R. S. Wankhade, S. S. Munje and Shubhangi Shelke. 2019. Study on BioEfficacy of Zinc Fortified SSP in Soybean. Int.J.Curr.Microbiol.App.Sci. 8(09): 707-713. doi: https://doi.org/10.20546/ijcmas.2019.809.085 